\title{
Contents, Vol 34, 1994
}

Founded 1897 as 'Monatsschrift fiir Psychiatrie und Neurologie',

continued 1957-1967 as 'Psychiatria et Neurologia'

Founders: C. Wernicke and Th. Ziehen.

Successors: K. Bonhoeffer (1912-1938), J. Klaesi (1939-1967), E. Griinthal (1953-1967),

H.E.Kaeser( 1968-1993)

Editor-in-Chief

J. Bogousslavsky, Lausanne

Associate Editors

J.G. Hildebrand, Brussels L.R. Caplan, Boston, Mass.

Associate Editor (IMeuroscience)

M. Fisher, Worcester, Mass.

Assistant Editor

Th. Kuntzer, Lausanne 


\section{Editorial Board}

\section{G. Benzi, Pavia}

Th.D. Bird, Seattle, Wash.

A.R. Damasio, Iowa City, Iowa

J. Dichgans, Tubingen

S. Di Donato, Milan

A.G. Engel, Rochester, Minn.

M. Fardeau, Paris

R.E. Gonsette, Melsbroek

J.H. Growdon, Boston, Mass.

S. Harel, Tel Aviv

C. Hess, Berne

L. Kappos, Basel

J. Kimura, Kyoto

A.D. Korczyn, Tel Aviv

P. Krauseneck, Bamberg

Th. Landis, Zurich

H.P. Ludin, St. Gallen

C. Loeb, Genova

P. Magistretti, Lausanne

O. Meienberg, Basel 
H.W. Moser, Baltimore, Md. J. Newsom-Davis, Oxford J. Olesen, Copenhagen Ch. Pierrot-Deseilligny, Paris H. Reichmann, Wurzburg P. Rondot, Paris W.A. Rocca, Florence A.B. Safran, Geneva G. Salamon, Marseilles

E. Satoyoshi, Tokyo

S.D. Shorvon, London

H.J. Steiger, Munich

W. Tackmann, Bonn

P.K. Thomas, London

A. Valavanis, Zurich

F. Vassella, Berne

J.P. Vonsattel, Boston, Mass. A. Yamadori, Himeji D.S. Zee, Baltimore, Md.

KARGEH

Medical and Scientific Publishers Basel $\bullet$ Freiburg $\bullet$ Paris $\bullet$ London New $\mid$ York $\bullet$ New Delhi $\bullet$ Bangkok Singapore $\bullet$ Tokyo $\bullet$ Sydney 
Drug Dosage

The authors and the publisher have exerted every effort to ensure that drug selection and dosage set forth in this text are in accord with current recommendations and practice at the time of publication. However, in view of ongoing research, changes in government regulations, and the constant flow of information relating to drug therapy and drug reactions, the reader is urged to check the package insert for each drug for any change in indications and dosage and for added warnings and precautions. This is particularly important when the recommended agent is a new and/or infrequently employed drug. 


\section{No.1}

Deprenyl and the Issue of Neuroprotection

Vingerhoets, F.J.G. Uitti, R.J; Calne, D.B.

Emerging Therapies in Neurology

New Drug Treatments in Epilepsy

Kuntzer, T.; Bogousslavsky, J.; Loiseau, P.; Richens, A.; Sanders, J.W.A.S.; O’Donoghue, M.

Original Papers

Borderzone Infarct Subtypes: Preliminary Study of the 11

Presumed Mechanism

Mounier-Vehier, F.; Leys, D.; Godefroy, O.; Rondepierre, $\mathrm{Ph}$

Marchau, M., Jr.; Pruvo, J.P.

Stroke Associated with Methamphetamine Inhalation 16

Yen, D.J.; Wang, S.J.; Ju, T.H.; Chen, C.C.; Liao, K.K.; Fuh, J.L.; Hu, H.H.

Correlation of Altered Q-T Interval and Sympathetic Nervous 23 System Dysfunction in Diabetic Autonomic Neuropathy Oka, H.; Mochio, S.; Sato, K.; Isogai, Y

Anti-Migraine Compounds Fail to Modulate the Propagation 30 of Cortical Spreading Depression in the Cat Kaube, H.; Goadsby, P.J.

Temporary Forced Laughter after Unilateral Strokes

Carnitine Analysis in Normal Human Red Blood Cells, 40

Plasma, and Muscle Tissue Reichmann, H.; Lindeneiner, N.v.

Short Report

The Effect of Inosiplex in Subacute Sclerosing Panencephalitis: 44 A Clinical and Laboratory Study Anlarar, B.; Yaläaz, K.; Imir, T.; Türanh̆, G.

Case Report

Axial Myoclonus Mediated by the Propriospinal Tract: 48

A Case Report

Nishiyama, K.; Ugawa, Y; Takeda, K.; Sakuta, M. 
Discs with Radiculopathy

Caplan,

Editorial

Primary and Secondary Prevention of Stroke in Patients with 61 Nonrheumatic Atrial Fibrillation Koudstaal, P.J.

Clinical Review

Hemorrhagic Infarcts 64

Moulin, T.; Crepin-Leblond, T.; Chopard, J.-L.; Bogousslavsky, J.

Original Papers

Myasthenia gravis Associated with Thymoma: Clinical 78

Characteristics and Long-Term Outcome

Palmisani, M.T.; Evoli, A.; Batocchi, A.P.; Provenzano, C; Tonali, P.

Evidence for Atrophy of the Corpus callosum in Alzheimer's 83

Disease

Vermersch, P.; Scheltens, P.; Barkhof, F.; Steinling, M.; Leys, D.

Spinal Dural Arteriovenous Fistulas: An Underestimated

Cause of Myelopathy

Bradac, G.B.; Daniele, D.; Riva, A.; Bracchi, M.; Stura, G; Riccio, A.; Pagni, C.A.

Single Muscle Fibre Analyses in 2 Brothers with Succinate

95

Dehydrogenase Deficiency Reichmann, H.; Angelini, C. 99

Hamann, G.F.; Isenberg, E.; Strittmatter, M.; Stoll, M.; Keshevar, T.; Moili, R.; Schimrigk, K.

Muscle Biopsy in Juvenile Distal Spinal Muscular Atrophy

103

Kao, K.-P.; Tsai, C.-P.

Case Report 
Hemiparkinsonism-Hemiatrophy Syndrome: Neuroradiologi- 107 cal and Neurophysiological Findings Costa, B.; Zanette, G.; Bertolasi, L.; Fiaschi, A. rs to the Edito

The Crow-Fukase (POEMS) Syndrome with Vasospastic 110

Angina

Yamada, M.; Yamawaki, M.; Michikawa, M.; Kameda, N.;

Furukawa, T.; Kaneko, E.

Creatine Phosphokinase-Linked Immunoglobulin in a Patient 111 with Hypokalemic Myopathy Arai, H.; Sakamaki, T.

Rabies Encephalitis Mimicking the Electrophysiological 113

Pattern of Brain Death Lang, C.

Reply 113

Issues in Neurologic Practice

Management of Patients with Lumbar Discs Herniations with 114

Radiculopathy

Caplan, L.R.

Clinical Review

Saccade and Smooth-Pursuit Impairment after Cerebral 121

Hemispheric Lesions Pierrot-Deseilligny, C.

Original Papers

17p 11.2 Duplication Is a Common Finding in Sporadic Cases 135 ofCharcot-Marie-ToothType 1

Mancardi, G.L.; Uccelli, A.; Bellone, E.; Sghirlanzoni, A.; Mandich, P.; Pareyson, D.; Schenone, A.; Abbruzzese, M.; Ajmar, F.

Comparison of Symptomatic and Asymptomatic Reinfarctions 140

rtical Stroke

Tohgi, H.; Chiba, K.; Takahashi, H.; Tamura, K.; Sasaki, K.; Suzuki, H.

Brief Remission Periods in Visuospatial Neglect: 147

Evidence from Long-Term Follow-Up Small, M.; Ellis, S.

Impotence Associated with the Charcot-Marie-Tooth

Syndrome

Bird, T.D.; Lipe, H.P.; Crabtree, L.D.

Human T. Lymphotropic Virus Type I Associated Myelopathy 158 and Myasthenia gravis: A Possible Association? Fukui, T.; Sugita, K.; Ichikawa, H.; Negishi, A.; Kasai, H.; Tsukagoshi, H.

Temporal Arteritis with Cerebral Complications: 162

Report of Four Cases

Buttner, T.; Heye, N.; Przuntek, H. 
Right Unilateral Agraphia following Callosal Infarction in a 168 Left-Hander

Tei, H.; Soma, Y.; Maruyama, S.

Hereditary Neuropathy with Liability to Pressure Palsies 173

Masquerading as Slowly Progressive Polyneuropathy Felice, K.J.; Poole, R.M.; Blaivas, M.; Albers, J.W.

Wernicke's Encephalopathy Induced by Hyperemesis gravida- 177 rum, Associated with Bilateral Caudate Lesions on Computed Tomography and Magnetic Resonance Imaging

Ohkoshi, N.; Ishii, A.; Shoji, S.

No. 4

Emerging Therapies in Neurology

Gene Therapy Prospects for Duchenne Muscular Dystrophy 181 Clemens, P.R.; Caskey, C.T.

Issues in Neurologic Practice

Should Single Epileptic Seizures Be Treated? 186

Caplan, L.R.; Sander, J.W.A.S.; Bromfield, E.B.; Leppik, I.E.

Original Papers 194

Cerebral Blood Change

Cerebral Blood Changes in Asymptomatic HIV-1-Positive and

-Negative Drug Addicts

Gomez Beldarrain, M.; Garcia-Monco, J.C.; Llorens, V.; Cortes, J.;

Mayo, J.

Double-Blind Trial of Dexamethasone versus Methylpredniso- 199

lone in Multiple Sclerosis Acute Relapses

La Mantia, L.; Eoli, M.; Milanese, C; Salmaggi, A.; Dufour, A.;

Torri, V.

Self-Assessed Cognitive Function in Snorers and Sleep Apneics. 204 An Epidemiological Study of 1,504 Females and Males Aged 30-60 Years: The Dan-MONIICA II Study Jennum, P.; Sjol, A.

Hepatic Myelopathy: A Rare Complication of Portacaval Shunt 209 Mendoza, G.; Marti-Fabregas, J.; Kulisevsky, J.; Escartin, A.

Concentrations of Carbamazepine and Carbamazepine-10,11-213

Epoxide in Serum, Brain Tumors and Paratumorous Cortex:

A Prospective Study of 37 Neurosurgically Treated Epileptic

Patients

Schnabel, R.; Rambeck, B.; May, T.W.; Jïrgens, U.; Lahl, R. 


\section{Contents}

Short Reports

Gm Haplotypes in Chronic Inflammatory Demyelinating 221

Polyradiculoneuropathy in Japanese Patients Yasuda, T.; Sobue, G.; Kumazawa, K.; Baba, M.; Saitoh, T.; Yanagi, T.; Mitsuma, T.; Miyazaki, T.

The Role of Mycobacterium tuberculosis in Experimental 224

Allergic Encephalomyelitis

Namer, I.J.; Steibel, J.; Poulet, P.; Mauss, Y.; Mohr, M.; Chambron, J.

Case Reports

See-Saw Nystagmus in a Patient with Clinically Definite MS 228 Samkoff, L.M.; Smith, C.R.

Dementia Syndrome in Patients with Postsurgical Hypopara- 230 thyroidism and Extensive Brain Calcifications Nicolai, A.; Lazzarino, L.G.

Leptomeningeal Infiltration in Esthesioneuroblastoma: 236

Report of Two Cases with Poor Prognosis Louboutin, J.P.; Maugard-Louboutin, C; Fumoleau, P.

Book Reviews 239

Erratum 240

Announcements 240

No. 5

Editorial

Gene Therapy in Neurology 241

Moser, H.W.

Original Papers

MRI Volumetry of Medial Temporal Lobe Structures in 243

Amnesia following Herpes simplex Encephalitis Yoneda, Y.; Mori, E.; Yamashita, H.; Yamadori, A.

Neuropathology of Late Cortical Cerebellar Atrophy in Japan: 253 Distribution of Cerebellar Change on an Autopsy Case and Review of Japanese Cases Tsuchiya, K.; Ozawa, E.; Saito, F.; Irie, H.; Mizutani, T.

Unaltered Respiratory Chain Enzyme Activity and Mitochon- 263

drial DNA in Skeletal Muscle from Patients with Idiopathic

Parkinson's Syndrome

Reichmann, H.; Janetzky, B.; Bischof, F.; Seibel, P.; Schols, L.;

Kuhn, W.; Przuntek, H. 
Pattern Reversal Visual Evoked Potentials in Minor Head 268 Injury

Papathanasopoulos, P.; Konstantinou, D.; Flaburiari, K.

Bezerianos, A.; Papadakis, N.; Papapetropoulos, T.

Cognitive Functions in Subjects with Incidental Cerebral 272

Hyperintensities

Fukui, T.; Sugita, K.; Sato, Y.; Takeuchi, T.; Tsukagoshi, H.

Awareness of Cognitive Deficits and Anosognosia in Probable 277

Alzheimer's Disease

Lopez, O.L.; Becker, J.T.; Somsak, D.; Dew, M.A.; DeKosky, S.T.

Case Report
Conduction Block in Vasculitic Neuropathy 283

Magistris, M.R.; Kohler, A.; Estade, M.

Letters to the Editor

Cheiro-Oral Syndrome with Intemuclear Ophthalmoplegia and 286 Cerebellar Ataxia following Midbrain Infarction Mochizuki, A.; Eto, H.; Takasu, M.; Utsunomiya, K.; Schoji, S.

Catecholamine Syndrome, Carcinoid Lung Tumor and Stroke 288 Nighoghossian, N.; Trouillas, P.; Loire, R.; Perrin, L.; Trillet, V.; Gamondes, P.

Atraumatic Temporal Lobe Pathology and Autobiographical 290

Memory

Babinsky, R.; Maier, B.; Calabrese, P.; Markowitsch, H.J.; Gehlen, W.

Cognitive Improvement following Treatment in a Case of 292

Idiopathic Hypoparathyroidism Lorusso, S.; Poli, V.; Casmiro, M.

Hemiplegia in Pregnancy due to Metastatic Cerebral Angiosar- 295

coma

Chaudhuri, K.R.; Jager, R.; Bridger, J.; Fusi, L.; Thomas, D.G.T.;

Frackowiak, R.S.J.

Sensory Perineuritis and Non-Hodgkin's T-Cell Lymphoma 298 Yamada, M.; Owada, K.; Eishi, Y.; Kato, A.; Yokota, T.; Furukawa, T.

Rotation-Induced Change of Muscle Tone 300

Kesselring, J.

No. 6

Editorial

Trends in Cerebrovascular Mortality in Western and Eastern 301

Europe

La Vecchia, C; Levi, F.

Review

Frontal Stroke Syndromes 306

Bogousslavsky, J.

Original Papers

Migrainous Stroke and the Antiphospholipid Antibodies 316

Silvestrini, M.; Matteis, M.; Troisi, E.; Cupini, L.M.; Zaccari, G.; Bernardi, G.

Sleep Problems in Multiple Sclerosis 320

Tachibana, N.; Howard, R.S.; Hirsch, N.P.; Miller, D.H.; Moseley, I.F.; Fish, D.

Influence of Clinical Variables on Neuropsychological 324

Performance in Multiple Sclerosis

Filippi, M.; Alberoni, M.; Martinelli, V.; Sirabian, G; Bressi, S.;

Canal, N.; Comi, G.

Colonic Transit Time in Nonidiopathic Parkinson's Syndrome 329 Jost, W.H.; Jung, G; Schimrigk, K.

Multiple Sclerosis with Very Late Onset: Report of Six Cases 332

and Review of the Literature

Azzimondi, G.; Stracciari, A.; Rinaldi, R.; D’Alessandro, R.;

Pazzaglia, P.

Short Reports

Pregnancy in a Patient with Wilson's Disease Treated with 337

D-Penicillamine and Zinc Sulfate. A Case Report and Review of the Literature Hartard, C; Kunze, K. 
Myotonia Induced by Potassium Repletion in a Diabetic

Patient with Secondary Hypokalemic Paralysis

Bertora, P.; Caccia, M.R.; Mangoni, A.

Ageusia Associated with Thalamic Plaque in Multiple Sclerosis 344 Combarros, O.; Miro, J.; Berciano, J.

Book Review 347

Announcements 347,348

Author Index Vol. 34, 1994349

Subject Index Vol. 34, 1994351

Suppl. 1

Epilepsy 1993. State of the Art

6th Cooperative Meeting on Epilepsy and EEG of Austria, Belgium,

Luxemburg and Switzerland

June 3-6,1993, Montreux, Switzerland

Guest Editors: G. Scollo-Lavizzari, Basel; H. Lechner, Graz

Suppl. 2

Advances in Migraine Management

Proceedings of the 2nd International Sumatriptan Symposium

Whistler, BC, Canada, September 11,1993

Guest Editors: J. Edmeads, North York, Ont.; K.M.A. Welch, Detroit, Mich.

Suppl. 3

2nd Sandoz Symposium on the Treatment of Parkinson's Disease

Tokyo, October 9, 1993

Guest Editor: I. Gotof, Fukuoka 
